\title{
Politics, Migration and Race: A Conversation with Yannis Hamilakis
}

Yannis Hamilakis is Joukowsky Family Professor of Archaeology and Professor of Modern Greek Studies at the Brown University (USA). His main research and teaching interests are the socio-politics of the past, the body and bodily senses, the archaeology of eating and drinking, the ontology and materiality of photography, archaeology and nationalism, archaeological ethnography, and critical pedagogy in archaeology. Yannis is committed to an anthropologically-informed, critical archaeological engagement with past and present material culture, and to the inter-disciplinary nature of archaeological work. This position recognises the historically contingent nature of archaeology as a device of western modernity, as well as its potential to enable a critical and reflexive experiential encounter with the material world. He also believes on a politically committed archaeological and academic practice, devoted to social justice.

Alessandro Pintucci: I am very glad to be here with Yannis Hamilakis, professor at the Brown University, thank you Yannis for joining us! Let's start from one of your first works, Archaeology and Capitalism, which is now 13 years old (Hamilakis and Duke 2007). The book addressed the complex relationship between Archaeology and Neoliberalism. In the introduction you voiced strong concerns about the gradual depoliticization of ethical debate in archaeology, increasingly focused "on interpretative issues having to do with the past, not the present". The book was first published in 2007, have we been able to reverse such trend?

Yannis Hamilakis: Thank you Alessandro, and I am very glad to be with you today. Let's go back a little bit and talk about the moment in which that book was published: 2007. It was prepared and written a few years earlier, based on a session held at the World Archaeology Congress in Washington DC. To give you some context: the papers were prepared and presented the year after the US led invasion in Iraq. None of the key issues debated at that moment at the WAC conference dealt with the archaeologists' involvement in that invasion as advisors to various militaries, especially the US and the UK military. So, we were witnessing a very strange phenomenon: a mass antiwar movement expressing a strong opposition to the war while, at the same time, some of our colleagues aligned themselves with the military in some way, on the grounds that they wanted to protect antiquities. So, they would give advice to the various authorities and militaries providing the so-called "no hit-lists", for archaeological sites and monuments to be spared when obviously a country like Iraq was carpet bombed by the US military and their allies, and for me that was a huge ethical and political issue to debate. That's why in 2003 I had published an article titled, An etbical crisis in Archaeology (Hamilakis 2003), using the Iraq war as a case study. My point was that you cannot continue debating the various ethical codes and the various kind of procedures that we have to follow, and yet at the 
same time on an issue of such a major importance for the world, do not question your own positionality. That was the background and the impetus for some of us to actually address the broader issue, and say: we are actually finding ourselves in a situation of bureaucratization, we are thinking about ethics in a procedural way, but not thinking about the political dimension of our own work, our own involvement with structures of power. At the same time, we were seeing our colleagues being very keen to adopt ethical codes, and that discussion was interesting and worthwhile because you were confronted with issues of ethical conduct, but we were extremely concerned with what we had seen as a split, a divide between the ethical and the political. The main argument of the book was thus to reconnect the ethical and the political. My main concept in the book's introduction was the political ethic, in the sense that you cannot separate the two, you cannot think ethics in the abstract, and divorce the ethical discussion from the political context of the moment and from questions such as, who is benefiting from the work of the archaeologists, and what is the involvement of archaeologists in the various apparatuses of power. Another issue that actually concerns us a lot at the moment has been the issue of the so called "contract archaeology" or CRM archaeology - something I am sure you know very well yourself - and the attitude by many of our colleagues to see that as another unproblematic sector of archaeology whereas we are saying: let's consider our own position vis-a-vis the Neoliberal mechanisms of the market; how, very often, the archaeologist working in those sectors provides an alibi, the green alibi for the remaking of whole landscapes, for the destruction of environments, for the reorganization of space and of human life along the lines of the market in a very unregulated, Neoliberal sense. So, these two kinds of phenomena for us were instrumental in gathering a group of people around and asking how we can actually revitalize discussion about politics and archaeology, and insist that politicization, in the sense of being reflexive and critical, needs to be an important facet and an important parameter of our work. As to your direct question, whether we have succeeded or not, I believe we have, to some extent. And that is not so much because of our intervention - although I do think that our book and our discussion helped a lot, and also other books by other colleagues that followed, of course we are not the only ones but also because of movements, because of what is happening in the world. Look around us now, at the various movements. Let's see the one I know fairly well because I work in the US: the Black Lives Matter movement, that actually has inserted a very important element in the discussion. That's the question of colonialism and of race. So, social movements, political developments, but also the rise of the extreme right and neo-fascism and neo-nazism in Europe and elsewhere are political developments that are actually confronting archaeologists with their own responsibilities. I would say that our critique helped to repoliticize archaeology. But developments, both from the right, like the rise of the extremist/fascist regimes and groups, and from the left such as anti-colonial and antiracist movements, actually helped move archaeology towards a more political direction. And now I think it's almost impossible for any contemporary archaeologist to deny the political role of archaeology and to maintain that they can actually continue working in their own bubble, in their own little world, and making no reference to what is happening in the world, to the political and social developments in our lives today. So I would say that I am optimistic. I am aware that there is still a lot to do, of course, there are so many fronts on which we need to be active and to confront the various situations. But I would 
say that we are now in a much better position to discuss openly the political dimension of archaeology than we were when we were writing this book.

Alessandro Pintucci: we come to the second question, which obviously is on the line of the first. One of your major lines of research seeks to apply the archaeological analytical process to interpret the present. From there stems your commitment to current issues such as the tragic condition of the refugees detained in Moria camp at Lesvos and the danger of those atrocities becoming the new normal. What role do you think archaeologist should or could play in the present?

Yannis Hamilakis: I think you can understand how an issue such as contemporary migration was important for me, especially since 2015, when Europe woke up to the phenomenon, partly because of the Syrian exodus, and partly because it became visible for the mainstream media and for Europeans as a whole. That phenomenon actually caused many people to rethink and reconsider many issues regarding European identity and policies. I talked about Black Lives Matter before. For me, contemporary migration is another phenomenon where colonialism makes itself present. These people, the peopleon-the-move are telling us: "You think we live in a postcolonial world? No, colonialism is still present, and we still live with the consequences of colonialism". Many of the people who are entering Europe come from previous European colonies or from areas that have been affected by recent neo-colonial wars such as the so-called War on Terror. So, there is that dimension, which is very important. In addition, the whole issue of national identity has been key in my own research (cf. Hamilakis 2007; Greenberg and Hamilakis 2022), and borders are also about national identities. So in relation to Greece, I wanted to see how conceptions of nationhood in Greece relate to phenomena of contemporary migration; how what we call now bordering practices relate to both the constitution of the nation and the whole project of Europe as "Fortress Europe", as an entity that proclaims itself the cradle of civilization and at the same time an entity that needs to protect itself by policing and militarizing the border, by not allowing people who are fleeing persecution or war to enter its own territory. As for what archaeology can do, as you know, contemporary archaeology has been a very recent and dynamic subfield of archaeology based on the premise that we archaeologists can interrogate the present, the contemporary world through our own skills and methods, and make the present less familiar in many ways, but at the same time examine carefully its materiality. Archaeology is about materiality and temporality, and the interplay, the intersection between the two. So for me, a phenomenon like migration can actually be explored very profitably by adopting archaeological lenses and optics but also an archaeological, multi-sensorial sensibility, archaeological ways of relating to matter and to time. And I am not saying "profitably" in the sense of extraction or exploitation or opportunism, I am saying it in the sense of a productive attempt to actually intervene in a phenomenon that has not been explored from the material point of view so much. If you look at the researchers who actually work on the phenomenon, they are very often social anthropologists, they are political scientists, they are specialists in migration studies or geopolitics. We in fact can be witnesses not only to the brutality of the border regime, which is very important, but also to the material dimensions of the phenomenon; explore not only what material traces the border crossing phenomenon leaves, but also how the apparatus of nation state and of Fortress Europe, 
the apparatus of the border, constructs its own materiality. So when I work on Lesvos at Moria, or in another context, I don't only record or reflect or think about what material traces border crossings leave, but also I am studying what new materialities that regime of the border creates. For me, a detention center or a refugee camp or an asylum service installation is equally worth investigating, so I am also turning the lens and the camera and the lights to the apparatus itself to the border regime and to the State and the European Union, not just to people-on-the-move. With people that cross borders, I am trying to have a relationship of collaboration and alliance and solidarity, so I see this as an activist project as much as a scholarly project; and very often the activist dimension takes priority over the scholarly dimension or the dimension of recording things. In terms of what we can contribute, I have already mentioned the emphasis on materiality and its recording of and study; I also mentioned the concept of witnessing. We can become witnesses to what is happening there, to the brutality of the border. But there is also the dimension of affectivity and of memory. By affectivity I mean that some of the remnants of migration have immense mnemonic and affective value, they can actually touch people and help them understand the phenomenon much better than an abstract narrative or a story. I am calling for the mobilization of the affective import and power of the object; certain objects can produce a space of witnessing and a space of understanding and of solidarity between, let's say, a border crosser from Iraq or Afghanistan and a European citizen in Rome or Athens or even an American citizen in Providence where we work, or New York. And finally, I believe that we archaeologists need to collect selectively some of the remnants of migration as it happens today, for archival and mnemonic reasons. There needs to be a material record of the phenomenon, beyond the narratives, beyond the written versions; there needs to be a collection of things that will speak to this specific moment, not only in terms of what these people are suffering very often, but also on what they achieve, on their resilience and inventiveness. I collect selectively from Lesvos things that have to do not only with the brutality of the border and its often tragic dimensions, but also with the achievements of border crossers as social agents: the objects they create, the recycling or upcycling they are involved in, the production of crafts and objects that come from life vests or other materials, or the paintings they paint while they are stuck in a refugee camp. All these things are important material signifiers of a moment. Let's speak of both the brutality of a border regime, and of the border as an assemblage with affirmative possibilities, of the resilience and the power of border crosses as agents of their own life (cf. Hamilakis In press a, and b).

Alessandro Pintucci: Much of your work focuses on the instrumentalization of archaeological narratives to build national identity, and Greece features often as an exemplary case study. This conference is held in Italy where we share the same rhetoric about classical past used as a national unifying tool. This is the paradox of our sector: archaeologists receive acknowledgement mostly when their function and freedom are instrumental to a collective national or local narrative. Do you think it is possible to find a mediation between these two dimensions? 
Yannis Hamilakis: That is a very interesting question. It is something that, obviously, is not an easy one, and it is something that have been thinking a lot about it in recent years. My short answer is yes, I do believe there is a way out. I do believe that there is a way of continuing, let's say, working on things from what we call the classical eras, and at the same time be critical, and not allow yourself to be coopted by the narrative of the nation or the narrative of a crypto-colonized and crypto-colonial country, as in the case of Greece (cf. Greenberg and Hamilakis 2022). Now you may know that I excavate earliest sites, neolithic sites in Greece. I do not work on the classical period as somebody who studies classical material and publishes as a classical archaeologist. But I do work on the classical as a phenomenon because of its key role in the constitution of the identity of Greece and the identity of the European so-called civilization as a whole. I know that many of my colleagues worry, especially my classical archaeology colleagues, that if we critique too much that phenomenon we lose our symbolic capital. We lose the authority that the classical, as an archetypal moment in the originary narratives about civilization, has in Western imagination. And my response to them is that, you can still maintain part of that capital if you explain why this phenomenon has become so important for the West. In other words, your historicization of the phenomenon, your implicit critique of it, can be as important as the actual study of things themselves. I am saying that there are people and the situation is changing also in European societies as well as in world more broadly today - who would be very interested to know why, how come that a specific moment in time in the Mediterranean became so important for the European imagination. I am proposing to turn this round and study it, in other words, as a phenomenon for reflection and critique and understanding as opposed to just produce admiring and uncritical narratives about how great these things and these societies were, how great the Greeks and the Romans were. And as I said, I believe that we should see such work in conjunction with recent developments in the European societies and other societies around the world. Again, I am returning to Black Lives Matter, because it is the movement of the moment, and one of the things that BLM has actually done is to make us reflect more on questions about race. Something that most of us, even people like me who have studied nationalism in all our working lives, have actually not confronted head-on, to the extent that actually needs to be confronted. I am currently rethinking many of my own ideas in relation to nationalism. I still believe that a lot of what I have said still holds, but I also believe that I needed to do, and now I am doing, I hope, more work on the racialized dimensions of the nation form and the nation project, in general and in relation to classical antiquity (see, for example, Greenberg and Hamilakis 2022). And I think we can actually ally ourselves with our non-archaeologist colleagues in classics, specialists in literature or history, who are doing a lot right now in reflecting on the racial dimensions of the classical phenomenon. Through that kind of alignments amongst ourselves, other colleagues in other fields who are actually exploring similar questions, and the broader social movements, we can manage to be both topical and speak to the present, but at the same time reflect seriously, deeply, and with scholarly rigor on the phenomenon itself.

Alessandro Pintucci: Thank you very much! 


\section{References}

HAMilakis, Y. 2003. Iraq, stewardship, and the "record". An ethical crisis for archaeology. Public Archaeology 3(2): 104-111.

Hamilakis, Y. 2007. The Nation and its Ruins: Antiquity, Archaeology, and National Imagination in Greece. Oxford: Oxford University Press.

HAMILAKIS, Y. In press(a). Food as affirmative biopolitics at the border: liminality, eating practices, and migration in the Mediterranean. World Archaeology.

HAMILAKIS, Y. In press (b). Border assemblages between surveillance and spectacle: what was Moria and what comes after? American Anthropologist.

Hamilakis, Y. and Duke, Ph. (eds) 2007. Archaeology and Capitalism: From Ethics to Politics. Left Coast Press.

Greenberg, R. \& Hamilakis, Y. 2022. Archaeology, Nation, and Race: Confronting the Past, Decolonizing the Future in Greece and Israel. Cambridge: Cambridge University Press. 